LA-UR-81-1748
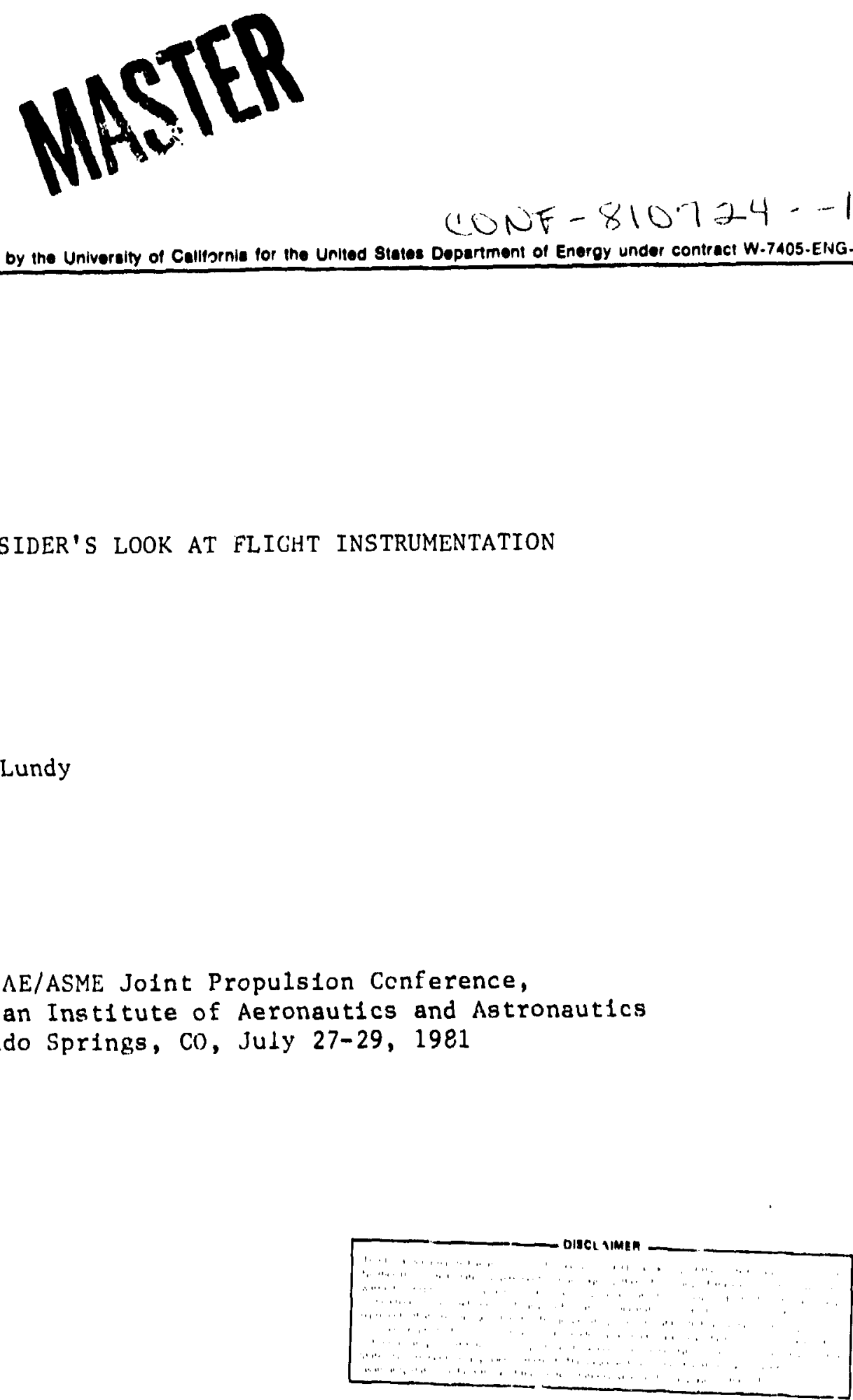


\title{
AN OUTSIDER'S LOOK AT FLIGHT INSTRUMENTATION*
}

\author{
Arvid S. Lundy** \\ Los Alamos National Laboratory \\ University of Californla \\ Los Alamos, New Mexico 87545
}

\section{Abstract}

The author has a varied background in medical and nuciear instrumentation, large particle accelerator control, and detonation diagnostics. He has recently been involved in hazard instrumentation for solid-propellantmotor ground tests.

This paper presents $h$ is ideas and speculations on possible diagnostic instrumentation for use in miss lle flight testing. A plea is inde for increased instrumentation efforts. Fiere is some discussion of telemetry methods.

\section{General Impressions and Author's Philosophy}

I belleve the instrumentation needs for a field a'e best determined by those individuals working in that field. Conversely, through my limited exposure to the solid-motor fleld, I have formed opintons critical of the quant ity of existing instrumentation efforts in that fteld. I want to share these opintons in a spirit of helpfulness, knowing that 1 am an outsider whose knowledge may he too meager to reach accurate concliusions.

Lord Keivin': statement that knowledge not expresstble in numbers is "of a meager and unsetlefactory kind" expresses an essential aspect of engineering. In the real world, it is mnasurenent instrumentation that must supply the numbers. John Cage of Hewlett Packard has said, "I think it is axlomat to that the instrumentation art mist grow faster than the science and engineer ing activifies Tn which nea sirement is necessary."

Judging by the number of papers published, that deal with propollant and combust ion sclence, the knowledge bare necessary in develop improved in lit propell sut motors is growing it a healthy rete. At the engineeriny deslan end of the suectrum, I belleve the performance history of solid moturs and the performance of racently designad motors such as this Spoce Shutt le hoosters and the Tridene. motori, indicste a matire technolony wit'i the developoud "rules of thumb" so necressary to any eng ineer iny technos ngy. Thern senms to be an understandinn gap however. in golmy from

laboratury propoll ant axper iments in enginnarend motors. At this point, I suspmet ignifleant imorovemant in on ild inctiors, taking advant dey" of advancens in combustlon and matarlals

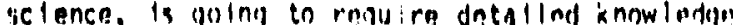
of what goess on within largn motors Turinn

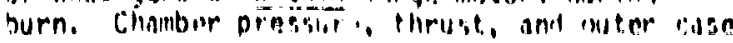
tempersfures

Whorked perf ormed unter the musplons of the U.S. Department of Enerily

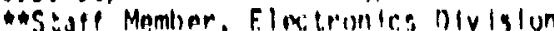

are not enough to optimize designs. Computer modeling must perlodically be verified in the real world. Detalled knowledge of instantaneous temperatures, gas and particle veloctties, densities, chemical composition, and stress throughout the motor during burn would seem highly desirable.

To obtain this data will require a significant effort in the development of transducers and new instrumentation techniques. Al though this session is primarlly concerned with flight instrumentation, the development of requitred techniques and transducers would strongly impact ground testing and basic propellant and combustion sclence experiments. The instrumentation need in these areas may be even greater. The National Research Council 1979 Hlgh Temperature Sclence report? states:

"The competition between analytical and experimental abllities to characterize combustion systems and processes shows experimentalists in danger of lagging behind modelers in the ir general capabllitles for probing hot, turbulent chemically reacting gases. The basic problem has been a lack of measurement sktlis for the rapidly fluetuating variables to be monitored."

Although the problems are obviously d!fflcult, they do not seem overwheiming in comparison to inany of the Instrumentation problems being dealt with today. Furthermore. the national energy situation is forcing attention to related instrumentation requirements in such areas as synthet ic fuels processing and gas turbine efflelency imprevement.

Looking at instrumentation sc.tivity ancther way, onn notes that most high technology research and developinent areas are also supporting significant instrumentintion development efforts. (The instrumentation art must grow faster than the sclenco and enginerring activitlos requlring measurunent.? Astromony, pa.tic in physics, and molecular blology, as woll as applind areess such as flission reactors. gcothumal power, medlic ine, and high-explosive. technolngy, sll supporl largn inst.rumentiation develizpinalle afforts. In all isf thase areas people arn work ing directly on development of instrumnentation torchninies and transducors in lishoritories mell guloped for such work and in close proximity to the focllle lies where such technigume and trallsdurers wlll be anpllode it ls ny impragston that sich activit las go on only in a vary lliniten iense wlithin the solite motor

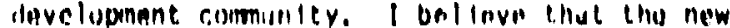
instrumentation rovel gninent that dous yo on in tills finled is malnly apoly ling new coumerclally doveloped produets. 
Another comparison might be made between flight testing an ICBM and an underground nuclear weapons test. I am guessing that the overall total cost of these activities is 0 ? the same order of magnicude. (I acknowledge that flight testing an ICBM involves much more than just flight testing the motors.) The instrumentation development budget for nuclear weapon tests appears to be very large in comparison to that for instrumentation development for flight testing. (Lord Kelvin and reasonable engineers would ask for budget numbers here. I have been unable to obtain

them.) In nuclear weapons test instrumencation deveiopment, the "state-of-the-art" is actively being advanced in such areas as high-speed oscilloscopes, high-speed analog to digital converters, fiber optic data transmission. image intensiflers, high-framing rate video cameras, wide bandwidth coaxlal cables, high-speed light detectors, laser diodes, and charge-coupled-device analog shift registers. In what areas of general instrumentation applicablitty is flight testing advancing the "state-of-the-art?"

My final arguinent for higher Instrumentation budoets concerns design simplicity. Many deople, myse if included. belleve weapons systems (and other high-technology sysiems) should be as simple as possible, even at some cost in performance. Simplicity usually translates into being economical, rellable, and maintainable. The key to design simplicity is realiy understanding how something works. of ten this understanding can only be obtained by using complex Inscrumentation during the development phase.

\section{Ii. Spec 1al Conditfor: Concerning \\ the Development of Flight Instrumentation}

In most flolds, the inst: umentation engineer has full control of the instrumentation froin selection of the transducer through data recording and of ten data analysis. In the flight instrumentation of solid propellant motors, this situation clearly doesn't exist. The instrumentation enginner at the motor cuntractor selects his transducers and conditlons the ir signais to inout to the telemetry systen, which is probabiy the responsiblitity, of the inissile system contractor located a days travel timn away. Here the telemetry englnaer designs his system to transmit. Jata to the fiight test range raicenlvers, which are another days travel timn awny. This chain is macle to wor!. by standardizing te and adequately documenting it. Still, if I ware the instrumintation englenur it the motor contractor. I would want at least mon chammel simply to sent a test generitine signal that would al? ow me to evalunter for mysnif tha amplituife, timing, and frequalley responie of the overall syatom.

If onn wants to do somathinn Inousat fur.

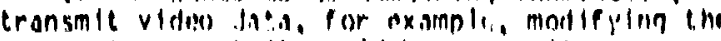
systam to acreat. it rould heronn: gulen Involvad. Clearly this gleuation is ond that

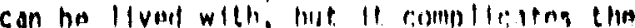

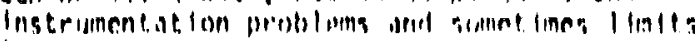
Inneivition.

\section{Conditions for Innovative} Instrumentation Development

I believe the following conditions and attitudes tend to lead to useful innovative development:

A. The person who wants certain data should be interested in precisely how the instrumentation engineer is going to obtain $i t$.

8. Instrumentation engineers should develop a personal concern with the complete system from "what is being measured and why" through "how the data analys is will be done." Too often, if the englneer does not have this concern, system features impose data artifacts that are falsely interpreted.

C. Variety usually leads to greater creativity. An instrumentation development englneer can frequently work on transducer development for several very different applications and can handle rout ine instrumentation for an upcoming test. Develnpment engineers shouid not be isolated from routine real world needs.

D. Adequate laboratory space and equipment for Instrument development, evaluation, and testing must be avallable on a permanent basis.

E. Electronics plays a key role in the majority of instrumentation work. A signif ti ant fraction of a group's instrumentation development englneers should be able to do analog and digital integrated circuit and discrete circult design work. These people should have avallable basic electronic test equipinent, as well as a stock of parts to allow rapidly assembling prototyoe circuits.

F. Other valuable knowledge that should be avallable lnc: Jdes physics, such as light and notics. scoustirs, rechinles, and huat transfer: knowledge oi materlal propert les and

fabrication: inicroprocessor application and programingi and applind inathematics including measuranent errur analys is.

G. Instrumentation development englneers must he able to koop up with the "state-of-the art." Thls should Include visits to othar instrumentat ion develoment factiltics. attendance at short rourses and professlond meet:ngs, and avallablifty of journals and texts.

H. Instrumentat lon anglileners must place hlgh prlorlty un guod communleatlons with others. They must. ferret out what new types of mensureinent ara limportant to be able to do. They nend to develun goud comnunleat lon l lnks with the ir nears work lny in other locat lons witlin thoir orqunleations ind with peors work ing on siniliar problans in other flelds and In othar organleatlons.

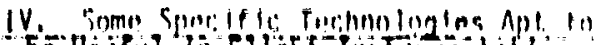

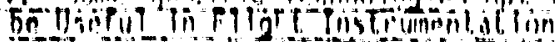

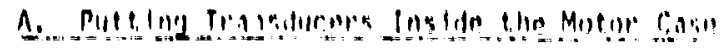

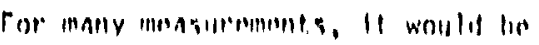


desirable to have transducers located inside the motor case. While being able to pass wires or fiber optics through the case would simplify data gathering, many motor designers prefer not to $r$ isk any additional holes in the pressure vessel. In this situation, either transformer coupling through the case or radio frequency transmission could be used both to power an internal data collection system and to transmit data out. Los Alamos has designed two passive transponder systems 3,4 for pulsed data interrogation of cattle and vehicles, that might be applicable to very low data rate situations.

In some cases, one might want electronic instrumentation capable of surviving and operating at high temperature within the case. Various Department of Energy programs ${ }^{5}$ are developing semiconductor devices capable of operating at $275^{\circ}$ to $350^{\circ} \mathrm{C}$. The Los Al am.ss integrated thermionics circult program 6 will provide circuttry usable to at least $550^{\circ} \mathrm{C}$.

Instrumentation placed within the case will need protection from the corrosive effects of chemicals present in the propellant. Parylene ${ }^{7}$ coating might provide very light weight, reliable solution to this problem.

Safety problems of electrical potentials embedded within the propellant need to be resolved, Los Alamos has had extensive experience with electrical potentials in high explosives and probably has relevant data avallable.

\section{Flber-0ptics}

Fiber-optics is a very rapidly growing fleld that in addition to providing communication links can also be used to construct transducers to measure temperature, pressure, sound, rotation, current, and magnet. ic rlelda: 1?. Other fiber-obtic. transducers based on light scattering measurements ${ }^{2} \mathrm{mlght}$ be devised for studying the combustion process ither within solid motors or vid the exhaust plume. Fiber-optic: can also be ised to couple infrared radiation thermomnters to normally inaccess blo areas 13 and to constrict flexible endosropes for using viden cameras to view inaccessible areas.

\section{Acoustir: and Uitrasonirs}

Acoustie dolextors mountar on inotor cascs might be usyfu! for diagnosing malfunction conditions 15.15 . The majni problem would probably lia interpretation of tim dinta. Acouitic ilonals as high as $300 \mathrm{kHz}$ have bunn recordend reom burning firiogellant and probabiv

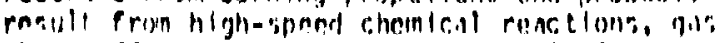
phase efenctis, and beating of signgls erom crystal hraskup and rasorangannnt

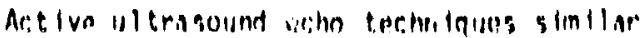

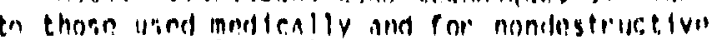

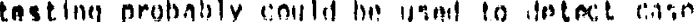

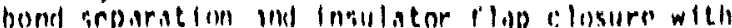

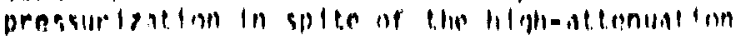

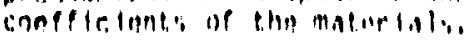

\section{Transient Data Recording}

Sometimes it is desired to record short duration transient signals that are too fast to transmit via the teiemetry system. An example might be sudden shocks lasting 10 to $20 \mathrm{\mu} \mathrm{sec}$ during stage separation.

A solution to this problem is to output the signal to a charge-coupled-device (CCD) analog shift register 76 running at 5 mega-sumples/ sec. Typical chips have about: 1000 stages so $\approx 200$ usec of data can he held. A level

discriminator at the input looks for any signal exceoding a preset threshold level. If a signal exceeds the preset level, the clock rate, after a preset delay (say 100 is sec), is shifted to ? low frequency, say $8 \mathrm{kHz}$. The data $c$ an now be transmitted over the telemetry system, having had its frequency shifted down by a factor of 625. A very compact transient frequency shift package with a weight of <150 grams can je built. CCO shift registers with a signal to noise ratio of $>55 \mathrm{db}$ are being billit by Fairchild Semiconductors and EG\&G Reticon.

\section{E. Video Systems}

High-quality video cameras hava decreased markedly in size in recent years. A color camera designed for surglcal applications is now avallable in a package weighing 172 grams, and $14 \mathrm{~cm}$ long by $3.8 \mathrm{~cm}$ in diameter 17 . Extremely rugged and compoct $C C D$ camerus are al so avallableis. Vartous intensified cameras for low-light conditlons and infrared sensitive cameras are avallable. I8 Los Alamos has used a moderately small, high-sensitivity $(0.05$ foot-candles), high-resclution (700 lines) ruggedized camera (Edo-Western Model 1831) Inside nuclear reactors. This unit is rated for operation from $-300 \mathrm{C}$ to $65^{\circ} \mathrm{C}, 150 \mathrm{~g}$ shock, and has no altitude limitations. The unit welghts $5: 0 \mathrm{~g}$ and is $2.8 \mathrm{~cm}$ in diameter by 13.2 cm long. Varlations on avallable vifeo cadmeras Include frame rate, resolutiun, image storage time, sensltivity, and signal format.

Orie applicat for for a video caliers would be to look at the forward dome through $\mathrm{s}$ wide angle lens to show dome rupture, should it occur. For this application, one would have to lisi! a low reso' llon, htoh-frame-raten camer i imaybe a 6Ay CC.D with a $5 \mathrm{MHz}$ clock alving 12.20 franes/sec) to al iow recording and transinteting - framu before hot gas hiles the lens.

The major difficulty in using video cameras is getiling a talumetry channel with wide enough bandwidth. Thls would probably requitre both a

suparate telemetry transinteter and deflcaltad recelvers in the ti:acking itat lons. Furthory discuerion is gluan in secition $V$. Telemetry and Data Acquisition.

Exteristyn a'rborne videa wark has beren dont

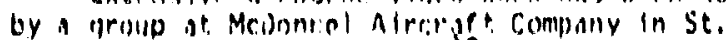

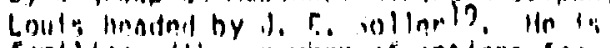

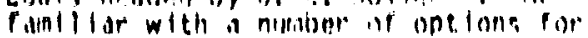
limpleninint Ino viden iysterns.

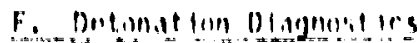


Los Alamos has had extensive experience in implementirg detendion diagnostics on ground tests. 20 pin switches that are activated by the arrival of a detonation wave can in principle be used on a flight vehicle. If several pin switches are mounted on the motor case and one accurately records the time (100-ns resolution) of arrival of the detonation wave at each switch, one can then calculate the origin of the detonation by trianoulation. Implementation on a flight vehicle would be difficult because of the wide bandwidth

(a $10 \mathrm{MHz}_{2}$ ) telemetry channels that would be required to transinit adequate timing data. Data probably could not be encoded and sent back at slower rates because in a detonacion scenario, the entire motor would be consumed $<500$ usec and telemetry fallure would probably occur very quickly theredfter.

Unless a wide-bandwidth dedicated telemetry channel were avallable, the... doesn't appear to Je any sure way to imr ..... detonatior diagnostics on a flig test.

\section{(i. Special Strain Transducer Needs:}

There is a need for strain gauges that could be embedded within the propellant. Another need is for ultra-high tempciature $\left(19000^{\circ}\right.$ to $\left.42 \mathrm{COOC}\right)$ strain measureinent techniques which could be used on exit cones made from composite materials.

\section{Telemetry and Data Acquistiton Systems}

Historically, the data acquisition systems used for aerospace telemetry were analog frequency-division-multiplex (FDM) systoms based on transducer signals frequency modulating (FM) sub-carrler osctllators ( $S \mathrm{CO}$ ) operating in the $400-H z$ to $180-k H z$ frequency range.?2 The nutputs of as many as ?. SCOS, each operating on a diffurent frequency, were combined to drive a FM transmitter operating in the VHF or UHF frequency range. On the ground the output of the telemetry rocotvers fed magnetic-tape? FM instrumentation racorders. Thn Range Cumrnandar's Cuunc 11 (RCC) Inter-Range Instrumentat inn Group (IRIRi) did impressive work in promoting standurds for such FM-FM tolemetry iystams and or ground-basod FM Initrumentiticion recorders.

I susDirl that. IRIG standarti for the FIA instrumnentation recorders have had a grigater positive offenct, an the overall Irstrimentintion effort in this ro.untry than any o:hnr aspect if flight instrumintation. These rovorters have Unen inportint. in blempllesl in'iterumentat fon,

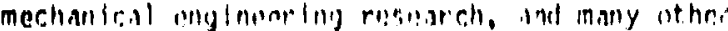
arens.

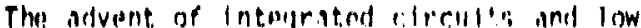
cost comnuture rosulting in merit dist acquisition systems iwitehing to digltal

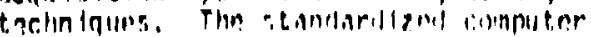

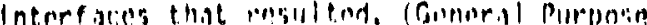

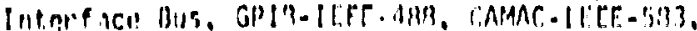

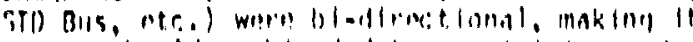

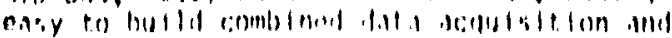

control systems with real-time modification of data taking parameters based on real-time anaiysis of the data. In many applicatlons single-channel data recording bandwidths now exceed $1 \mathrm{GHz}$ and computer interfaced transient digitizers allow short burst data recording of these bandwidths.

Flight instrumentation also went digital, but in a somewhat differcnt fashion. 22 In the time division multiplex (TOM) systems, transducer signals are fed through analog multiplexers to analog-to-digital converters, the outputs of which drive pulse-code-modulation (PCM) encoders. The serial or parallel output from the PCM encoders modulates the telemetry transmitter. On the ground, the output of the telemetry receivers feeds the PCM data to PCM magnetic-tape instrumentation recorders, which have evolved from the IRIG standard FM tape recorders. Indeed, one can buy instrumentation recorders thas by the simple change of plug-in modules can be converted from analog tirect, to analog FM, to digital $P C M$ recording. The data recording rate of these systems is quite impressive; a single instrumentation recorder may record data at $>80 \mathrm{Mb} / \mathrm{t} / \mathrm{sec}$. The tapes from the PiM recorders are played back into computer systems for data reduction and output.

The PCM ifgital telemetry systems wers devtloped under IRIG standards. Most missile telemetry transmission is now done at S-band (2200 to $2300 \mathrm{MHz}$ ). Tracking parabolic dish antennas with low notse preamplifters, and diversfty recelving systems based on right-hand circular and left-hind circular polaritation directions are used.

The conversion of the FM-FM analog telnmetry systems to the TOM digltal systems is most impressive co me. These systems seem to be very flexible, and the input subsystems are designed ldenticallv to common ground based computerized dita acquisition systems. The recent incorporation of microprocesicrs in the missile Jata system allows data sampling rates and channel gains to he varled accordirig to preprogrammed Instructlons, and could evon vary paraneters in accordince with tho real-time incoining dita. This should groaily expand the number of useful data acquisition channols. The range of data simpling rates prograimable on one system currently unier design include: 700 measuriments at 1000 sinples/sec, 100 measurements at 8000 inmple/ser, and one measur oment. at $19 ?, 000$ sanples/soc (all at 3-b/t. occuracy).

For most apolleations, the ibnve data loggling rates are! Impressive. if howiver, ont

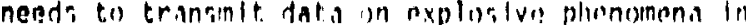

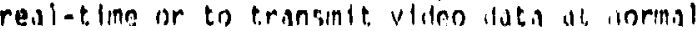
v/del) ratos ( 30 frames/sec) or h/ghall, the system s imply disn:' not premlt 11. Tho 192,000)

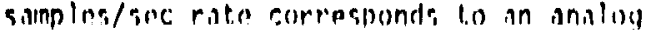

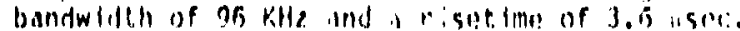

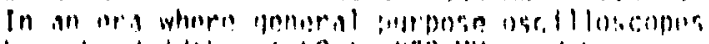

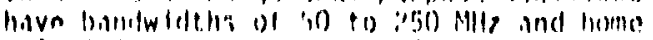

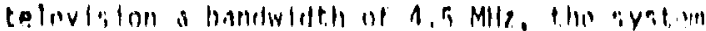
serme; virey llinitiol.

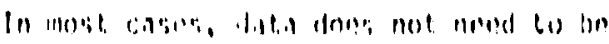


transmitted in real time, and analog CCD shift registers or more complex on-board transient digitizer techniques using storage in digital memories could easily record wide bandwidth data. Subsequent transmission at reduced speed could be done on the standard PCM telemetry system. Probably a high percentage of video applications could be satisfied by transmitting only a few frames at low speed, provided those frames were initially recorded at nigh speed. The electronics to do this exists now and will rapidly sirink in size, weight, and cost with the advent of large-scale integration.

Techniques exist to transmit video data or other wide bandwidth data in real time. Both White Sands and Cape Canaveral have some capubilit, to receive and record video data on standard video tape. In a system used at Edwards AFB, a separate S-band telemetry transmitter on an alrcraft is FM modulated with a deviation of $16 \mathrm{MHz}$ by the signal from two video caneras. On the ground, a standard telemetry receiver, with an added wide bandwidth detector, outputs the signal to a standard video recorder. All components are commercially avallable. At Cape Canaveral. TV data from a chase $p l$ ane transmitting on $C$-band using satellite TV format is recorded during Space Shuttle launches.

Many people feel that there is little need for wide bandwidth data or video while others think that it would be useful. I cannot judge the usefulness, but it is possible to transmit such data now (with some difficulty), and it will become increasingly easy tu do sn in the future.

\section{Conclusions}

i belleve the solid motor deva?opment community could profltably increase its instrumn: ition nfforts. As an outstifer, I do not see inany developed instrumentation tachn inuns which can simply be pluggen in to solve axisting flight instrumentition problems. I do sce, i number of technlogins, hovevier, that seem potents ally very useful with relatively small effort for both flight and ground teest. applications.

1 want to express my apprectation to the pcoples in the solfil-propellant motos and telemetry communtles wha spent time dlscusing varlous instrumentation problems with me. However I want to strers that I take filil responsibllity for the opintons axpresserl in this paper. Furthermorn, the nointons

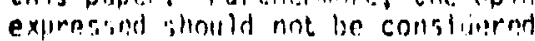
representiat lun of the line Rlamns Nationn Laboritiory or the Dapartunent of Ennrigy.

\section{Refornng:ne}

1. Berllard M. Olivier and lolin M. Cantor.

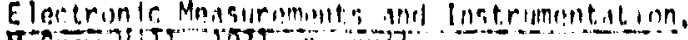

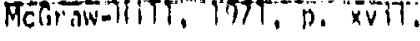

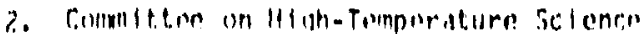

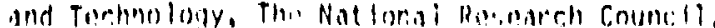



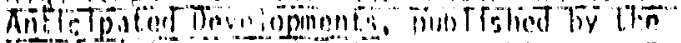

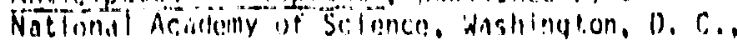
1979, p. 18-52, 105-15.
3. A. R. Koelle, J. A. Landt, R. E. Bobbett, and P. H. Salazar, "Technical Aspects of Electronic Identification and Temperature Monitoring System," LA-7641-MS, March 1979.

4. J. A. Landt, R. E. Bobbett, A. R. Koelle, and $P$. H. Salazar. "The Los Alamos Scientific Laboratory Electronic Vehicle Ident ification System," LA-7818-MS, May 1979.

5. Anthony F. Veneruso, "High Temperature Technology Potential, Promise, and Payoff," Electro/80 Conference Record, May 13-15, Bosten, Mass achusetts, p. 16/0, 1-6.

6. Byron McCormick, et al., "Development of Integrated Themionic Circuits for High Temperature Applications," Proceedings of the Conference on High-Temperature Electronics, Tucson, Arizona, March 25-27, T981, p. 49.

7. Parylene is a Union Carbide Corporation developed vapor-deposited conformal coating with good electrical and mechanical properties from $-2.000 \mathrm{C}$ to $275^{\circ} \mathrm{C}$.

8. G. B. Hocker, "Fiber-Optic Sensing of Pressure and Temperature," Applied Opt ics, Vol. 8, No. 9, 1 May 1979, p.' 1445-8.

9. W. B. Splliman, ur., "Multimode Fiber-0ptic Hydrophone Based on a Schloren Technique," Applied Optics, Vol. 20, No. 3, 1 February 198T, $2.465-70$.

10. W. C. Goss, R. Goldstein, M. D. Nelson, H. T. Fearnehaugh, and 0 . G. Ramer, "Fiber-Ootic Rotation Sensor Technology," Appl led Optirs, Vol. 19, No. 6, 15 March 1980, p. 352-3.

11. A. Tapp and 1\%. Harms, "Magnetopt (cal Current Transforiner," Appliell Optir.s. Vol. 19 No. 22, 15 November 15, 9980, p. 3729-45.

12. S, C. Rashleigh, "Magnetic-Fieid Sensing with a Single-Mode Fiber." Optics Letters. Vol 6. No. i, January ig8 ,. $19-21$.

13. Anthony J. Intrieri, "Optical Fiber's Look Around Obstacles to Measure Temperature," Control Englnearlng. Decomber 1977, p. 42-44.

14. A. J. Saber, M. D. Johnston, L. H. Caveny, and $M$. Summerfleld, "Acoust ic Emisstons from Burning Propellant: Stranc's," Procedilnus of l1th JAindaF Combust lun Meot lug.

15. Jolur L. E\{sel, "Vibration Rosponsen Spectruccony-Fxtens inn of Acoustic Fmissilon Technigues to Combusion Dinunorit ic Usa" Trechnicil Mrmor indum 3070. Navil Wrapens Contor. Chilla l.akn. Collfarnti 93555. Apr 11 1977.

16. A. B. Shopherd and P. Descura. "Charye

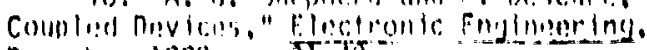

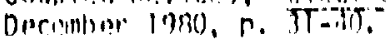

17. Nowr; Rolo.15!! NRB1-1R, (1981) G Arrom

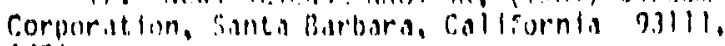
1981. 
18. Char les F. Freeman, Editor, "Recent Advances in TV Sensors and Systems,"

Proceedings of the Society of Photo-Optica? Instrumentation Engineers, VoT. 203, August 27-28, 1979, San Diego, California.

19. J. E. Soller, "Airhorne Video Instrumentation/Data Reduction," Society of Flight Test Engineers, Proceedings of Toth Annual Symposium, Las Vejas, Nevada, September $4-6,1979$.

20. A. S. Lundy, J. B. Ramsay, A. L.

Criscuolo, A. D. Martin, J. A. Montoya, and J. R. Parker, "remporal and Spatial location of the Transistion-To-Detonation Point in

Propellant Grains," presented at 16th JANNAF Combustion Meeting, Monterey, California, Septerber 1979, unpubl ished (LA-UR-79-2960).

21. Harnit J. Jeske, "Performance Characteristics of Te? temetry Transmission Systems," Tutorial Proceedings of the 22nd Internat ional ISA Instrument ation Sympos ium, May 25-27, T976, san liego, Californta

(Fundamentals of Aerospace Instrumentation Vol. 8) p. 109-119.

22. Charles S. Johnson, "An Introduction to Telemetry Data Systems," ibid, p. 127-39. 